\title{
From Galvani to patch clamp: the development of electrophysiology
}

\author{
Alexei Verkhratsky • O. A. Krishtal • Ole H. Petersen
}

Received: 7 September 2006 / Accepted: 10 September 2006 / Published online: 28 October 2006

(C) Springer-Verlag 2006

\begin{abstract}
The development of electrophysiology is traced from the early beginnings represented by the work of the Dutch microscopist, Jan Swammerdam, in the 17th century through the first notion of an aqueous transmembrane pore as a substrate of excitability made by Luigi Galvani in late 18 th century to the invention late in the 20th century of the patch-clamp technique by Erwin Neher and Bert Sakmann.
\end{abstract}

Keywords Swammerdam · Galvani · Aldini · Volta ·

Bois-Reymond · Helmholtz · Bernstein · Overton ·

Cole and Curtis · Hodgkin and Huxley · Neher and Sakmann .

Electrophysiology $\cdot$ Patch-clamp $\cdot$ History

\section{The beginning: the prophecy of Galvani}

I am attacked by two very opposite sects-the scientists and the know-nothings. Both laugh at me-

\footnotetext{
A. Verkhratsky $(\bowtie)$

Faculty of Life Sciences, The University of Manchester,

Manchester M13 9PT, UK

e-mail: alex.verkhratysky@manchester.ac.uk

O. A. Krishtal

Bogomoletz Institute of Physiology,

Bogomoletz St. 4,

Kiev, Ukraine

O. H. Petersen

MRC Group, Physiological Laboratory,

The University of Liverpool,

Crown Street,

Liverpool L69 3BX, UK
}

calling me "the frogs' dancing-master". Yet I know that I have discovered one of the greatest forces in nature. Luigi Galvani

The foundations of experimental electrophysiology were laid in the 1660s, when the Dutch microscopist and natural scientist, Jan Swammerdam [12], developed a neuromuscular preparation (Fig. 1). Swammerdam used the frog leg, from which "one of the largest muscles be separated from the thigh of a Frog, and, together with its adherent nerve, prepared in such a manner as to remain unhurt" $[12,74]$. Stimulation of the nerve (which Swammerdam called "irritation") triggered muscle contraction. Subsequently, he further perfected the preparation, by inserting the muscle into a glass tube and attaching needles to each of the muscle ends (Fig. 1b).

The contraction, initiated by nerve stimulation, could therefore, be monitored via the movements of needles, and in principle, these needles could be used for contraction recording (e.g., charcoaled paper-although we do not know whether such recordings were ever made). Moreover, in one of his experiments, the nerve was fixed by a brass ring, and the "irritation" was done by a silver wire (Fig. 1c); an arrangement that could cause true electrical stimulation $[12,71]$. Swammerdam came close to understanding the nature of signal propagation between nerves and muscles, but it was Isaac Newton, who first contemplated the electrical nature of nerve signals, introducing the idea that "electric bodies operate to greater distances....and all sensation is excited, and the members of animal bodies move at the command of the will, namely, by the vibrations of this spirit, mutually propagated along the solid filaments of the nerves, from the outward organs of sense to the brain and from the brain 


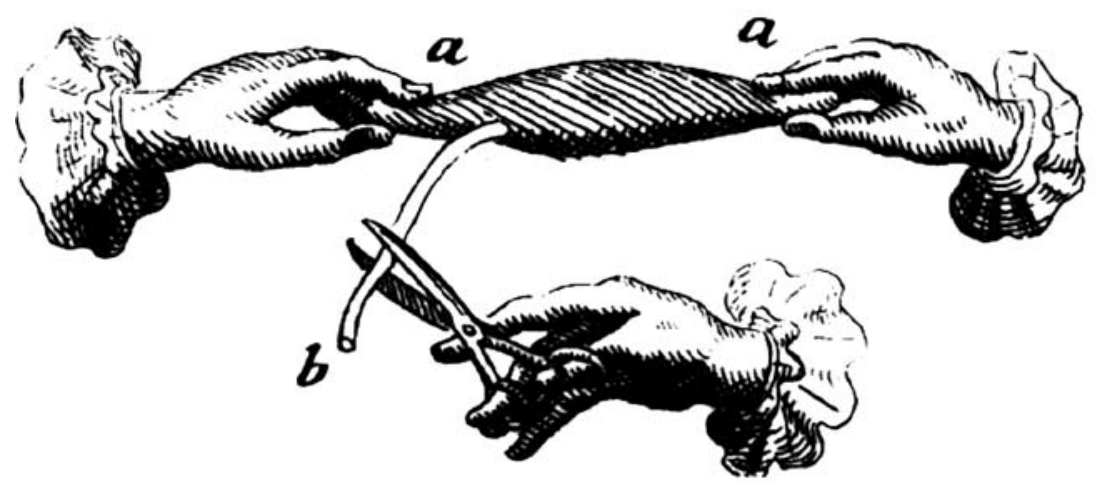

Fig.V.

b
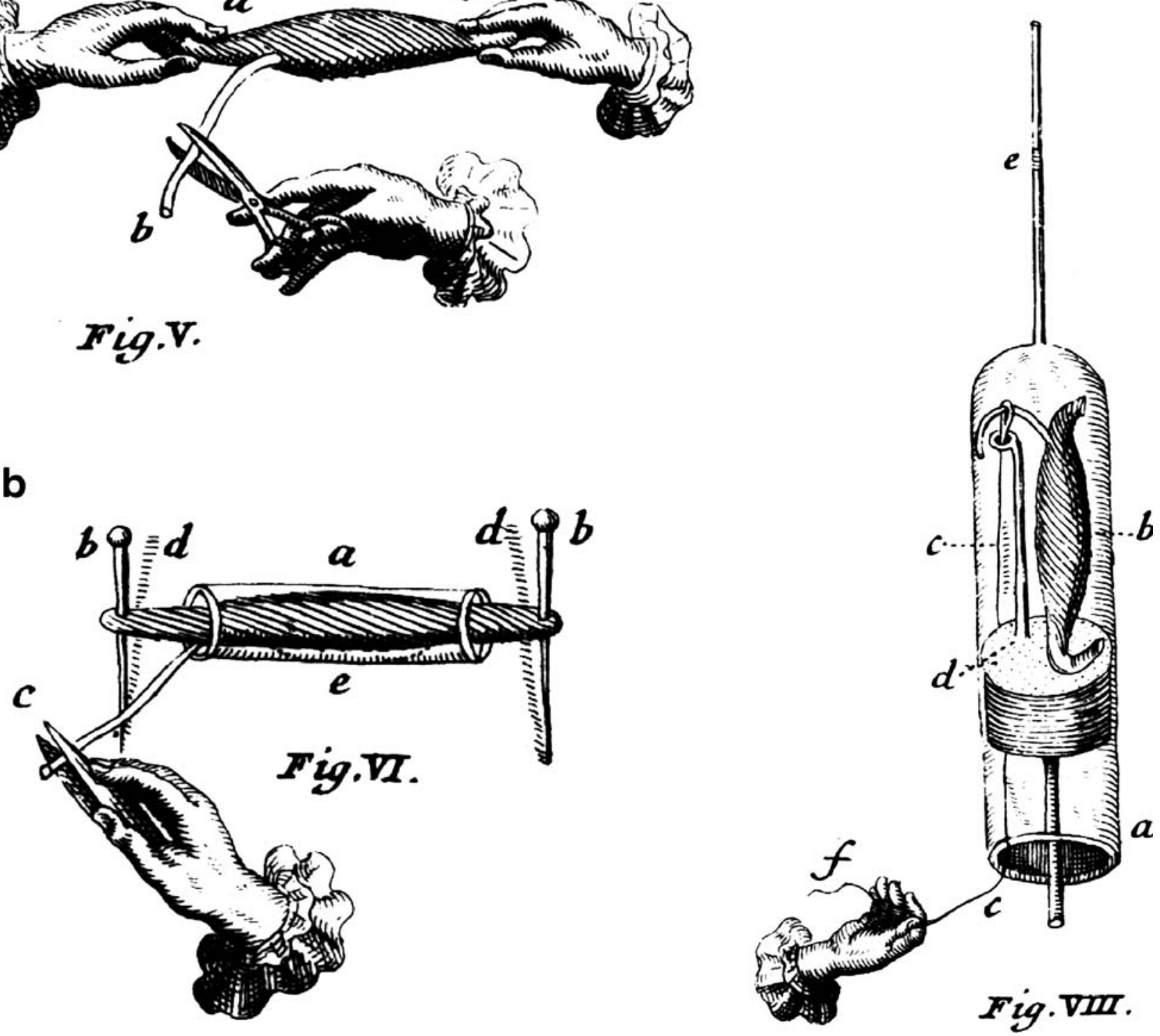

Fig. 1 Neuromuscular preparations of Jan Swammerdam, with his original descriptions (Images [74] and quotations were kindly provided by Dr. Mathew Cobb, University of Manchester; see also $[11,12])$. a "if $[\ldots]$ you take hold, $a a$, of each tendon with your hand, and then, irritate $b$, the propending nerve, with scissors or any other instrument, the muscle will recover its former motion, which it had lost. You will see that it is immediately contracted and draws together, as it were, both the hands, which hold the tendons." b "If we have a mind to observe, very exactly, in what degree the muscle thickens in its contraction and how far its tendons approach towards each other, we must put the muscle into a glass tube, $a$, and run two fine needles, $b b$, through its tendons, where they had been before held by the fingers; and then fix the points of those needles, neither too

into the muscles. But these are things that cannot be explained in few words, nor are we furnished with that sufficiency of experiments which is required to an accurate determination and demonstration of the laws by which this electric and elastic spirit operates" [51]. loose nor too firmly, in a piece of cork. If afterwards you irritate, $c$, the nerves, you will see the muscle drawing, $d d$, the heads of the needles together out of the paces; and that the belly of the muscle itself becomes considerably thicker, $e$, in the cavity of the glass tube, and stops up the whole tube, after expelling the air. This continues till the contraction ceases, and the needles then move back into their former places." c The stimulation of neuromuscular preparation by silver wire." a) The glass tube, or siphon. b) The muscle. c) A silver wire with a ring in it, through which the nerve passes. d) A bras wire... through which the silver wire passes. $e$ ) A drop of water in glass tube. $f$ ) The hand that irritates the nerve, in consequence of which irritation the drop on the muscle, contracting itself, descends a little"

Experimental support for the electric nature of nerve impulse was furnished 80 years later, and the story of ion channels began in 1791, when Luigi Galvani published his fundamental work, De Viribus Electricitatis in Motu Musculari Commentarius [19], on animal electricity. This was a 
description of 10 years of observations on contraction of isolated frog nerve-muscle preparations, which Galvani performed with his wife, Lucia Galeazzi, and his nephew, Giovanni Aldini.

Initially, Galvani used his version of the nerve muscle preparation (Fig. 2), which consisted of the inferior limbs with the crural nerves, connecting the spinal cord with the limbs, fully exposed, and a metal wire was inserted across the vertebral canal $[19,21,64,65]$. Using this preparation, Galvani identified electrical excitation of the nerve-muscle preparation, found the relationship between stimulus intensity and muscle contraction (the latter showed saturationi.e., increasing the intensity of stimulation above a certain strength did not result in an increased magnitude of contraction) and described the refractory phenomenon by
Fig. 2 Experiments of Luigi Galvani (images for Figs. 2 and 3 were kindly provided by Prof. Marco Piccolino, University of Ferrara) a Plate I of the Commentarius [19] shows the frog preparation and the electric machine. b Plate III of the Commentarius [19] shows the experiments with metallic arcs

\section{a}

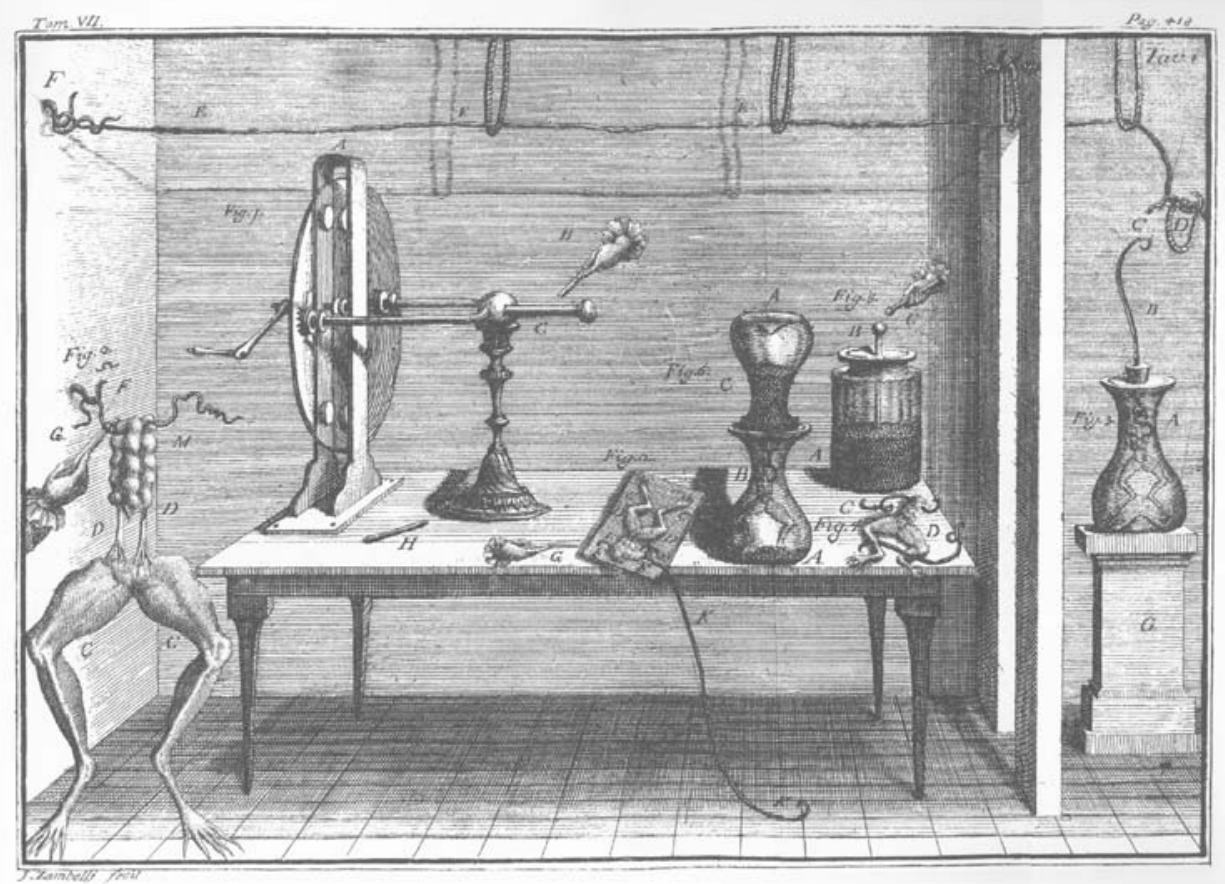

b

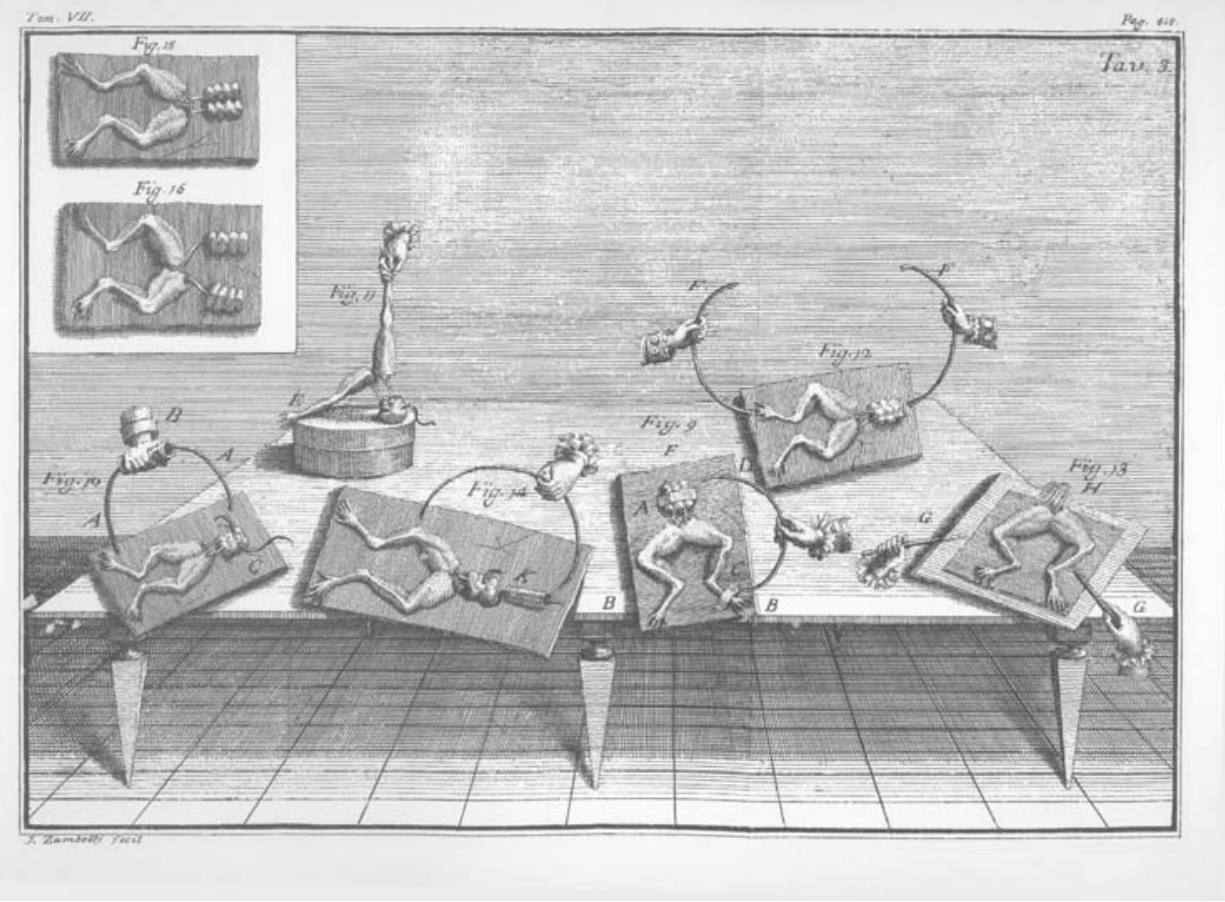


showing that repeated stimulation leads to disappearance of contractions, which can be restored after a period of rest.

The crucial experiments, however, took place in 1794 1797 [21, 65], when Galvani used two frog legs with long sciatic nerves attached (Fig. 3). When the nerve of the first preparation was in contact with the nerve or muscle of the second, contraction occurred in both preparations. This was the first demonstration of a propagating action potential.

Based on his experimental achievements, Galvani developed the theory of electrical excitation. First, he realized that biological tissues exist in a state of 'disequilibrium', i.e., at rest, the tissue is ready to respond to external stimuli by generating electrical signals. Even more importantly, Galvani postulated that "animal electricity" results from accumulation of positive and negative charges on external and internal surfaces of the muscle or nerve fibre, which he compared to the internal and external plates of the Leyden jar [20, 65]. The electrical current flow, which occurs during excitation, required a specific pathway, and Galvani contemplated the existence of water-filled channels, which penetrate the surface of the fibres and allow the electrical excitability. Once more, comparing the biological tissue to a Leyden jar, he wrote: '...let one plaster then this conductor with some insulating substance, as wax... let one make small holes in some part of the plastering that concerns the conductor. Then let one moist with water or with some other conductive fluid all the plastering, having care that the fluid penetrate in the above mentioned holes, and come in contact with the conductor itself. Certainly, in this case, there is communication through this fluid between the internal and the external surface of the jar' ([20], quoted from [64]).

Galvani's findings had rapidly resonated through the world. First, they inspired a fierce fight with Alessandro Volta, who vehemently opposed the concept of animal electricity [76]; Volta's experiments, although proven wrong as far as biology was concerned, resulted in fundamental discoveries in the general theory of electricity and the invention of the electric battery in 1800. More importantly, however, the idea of galvanism became a cultural phenomenon and spread throughout Europe with lightening speed. Particularly illustrious were the demonstrations of Giovanni Aldini, who, after the untimely death of Galvani in 1798, continued investigations of animal electricity. In 1803-1804, Aldini published important books, which combined the ideas of Galvani and Volta and made a coherent theory of electrical excitation of biological tissues [1, 2]. He also made the most exciting electrical stimulations of body parts of freshly executed criminals, which made a huge impact on the general public. So invigorating was the theory of galvanism that in 1817, it inspired Mary Shelly to write "Frankenstein, or the Modern Prometheus", the novel, which for the first time addressed the problem of the responsibility of the scientist for the products of his mind and hands. Beside these demonstrations, Aldini made many other fundamental observations; in particular, he was the first to apply electrical currents to mammalian brains and found that stimulation of the corpus callosum and cerebellum triggered pronounced motor responses (the experiments were done on the ox brain in situ, with the scull opened and all brain-spinal cord connections remaining intact $[1,2])$.

\section{The instrumental period}

The first instrumental recording of animal electricity (using the frog neuromuscular preparation), was made by Leopoldo Nobili, with the aid of an electromagnetic galvanometer [53], although Nobili interpreted this recording in strictly physical terms, suggesting that he was measuring a thermoelectrical current resulting from unequal cooling of the two ends of the preparation. Several years later, in 1842, Carlo Matteucci repeated this experiment and
Fig. 3 Galvani experiments of the contraction without metals [21]. a The 1794 experiment: when the surface of section of the nerve touches the muscle the leg contracts; b the 1797 experiment: when the surface of section of the right sciatic nerve touches the intact surface of the left sciatic nerve, both legs contract
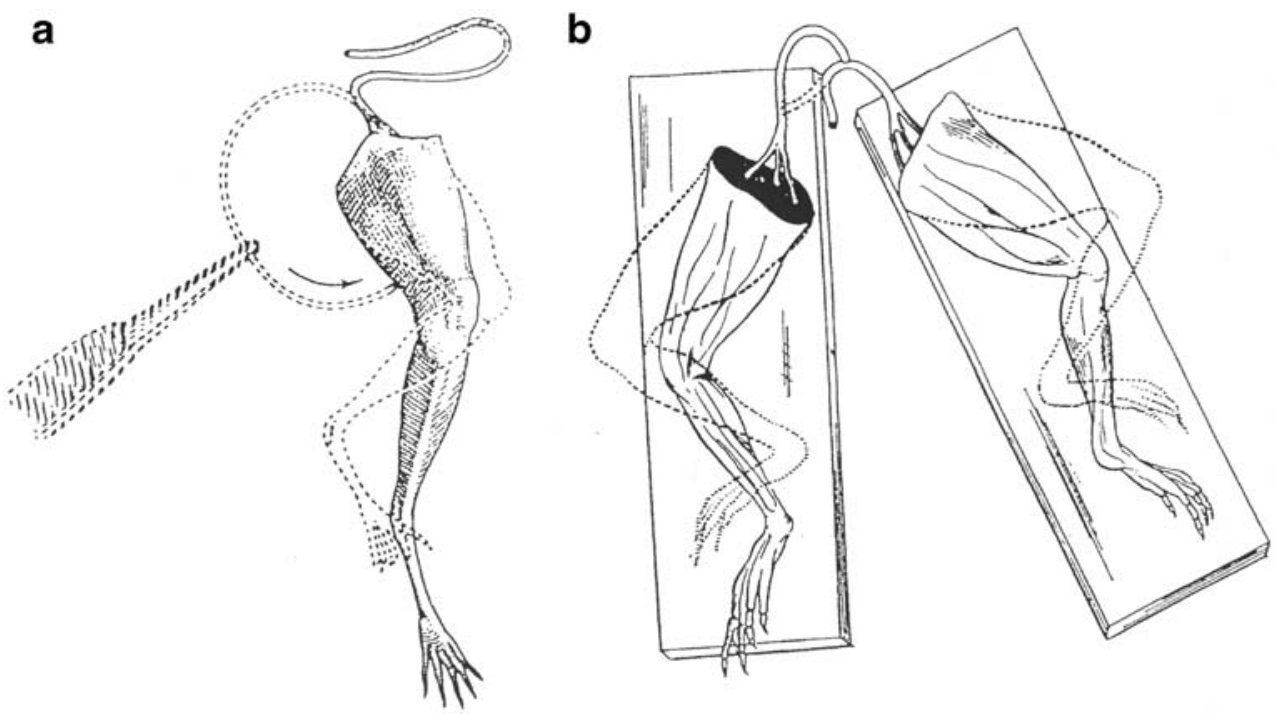


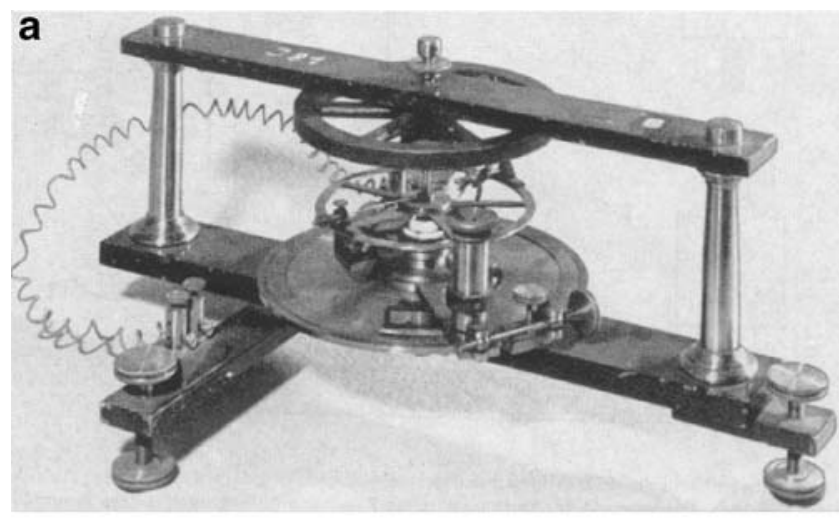

b

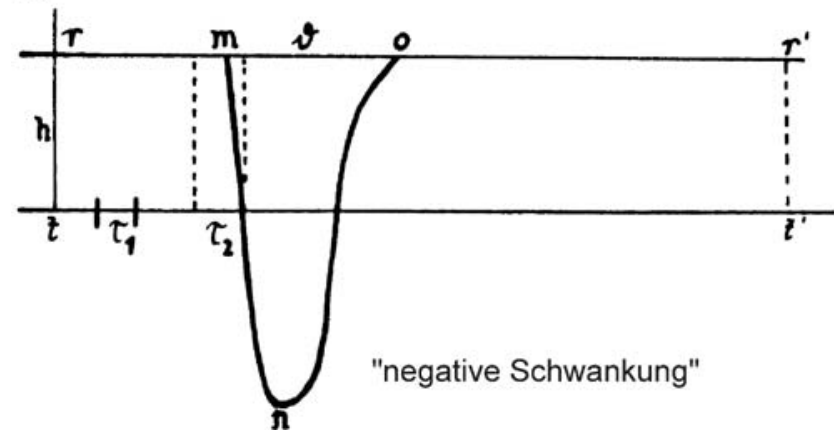

Fig. 4 First recording of action potential from the nerve made by Julius Bernstein $[6,52]$; original images were kindly provided by Prof. Bernd Nilius, University of Leuven. a The Bernstein rheotome; $\mathbf{b}$ the recording of an action potential. The $\tau_{1}$ and $\tau_{2}$ indicate "sampling" intervals of the rheotome; the duration $m-O$ is the duration of action potential ["negative Schwankung", and $n$ is the "sign reversal" (overshoot)]

demonstrated that the galvanometer reading was the exclusive consequence of currents generated by the living tissue [47]. Furthermore, Matteucci succeeded in measuring the resting current between the intact and cut surface of the muscle [46]. The next step was made by Emile du BoisReymond, who was able to measure electrical events accompanying the excitation of nerve and muscle, and realized that excitation greatly decreases the potential difference between the intact surface and the cut portion of the tissue - hence, he called the excitatory electrical response the "negative Schwankung" (negative fluctuation) [17].

In 1850-1852, another fundamental discovery was made when Hermann von Helmholtz, using the nerve-muscle preparation, determined the speed of nerve impulse propagation by measuring the delay between the application of an electrical stimulus and the muscle contraction [24]. Furthermore, Helmholtz for the first time, used a smoked drum to record muscle contractions [25]. To measure the velocity of nerve impulse propagation, Helmholtz used a technique developed by Claude Pouillet, who found that galvanometer excursions induced by brief pulses of current were proportional to the pulse duration [66]; incidentally, this technique was successfully used in military practice for determining the speed of cannon balls. By using this method, Helmholtz was able to determine the delay between electrical stimulation of the nerve and muscle contraction, a delay, which he rather poetically defined as "le temps perdu" (the lost time) [24, 66].

The speed of nerve impulse propagation measured by Helmholtz caused some confusion: the values of the propagation velocity were in the range of $25-40 \mathrm{~m} / \mathrm{s}$, which was much slower than the propagation of electric current. It was somehow difficult to correlate the Helmholtz data with the excitatory currents of Dubois-Reimond, as the time resolution of the contemporary techniques did not allow
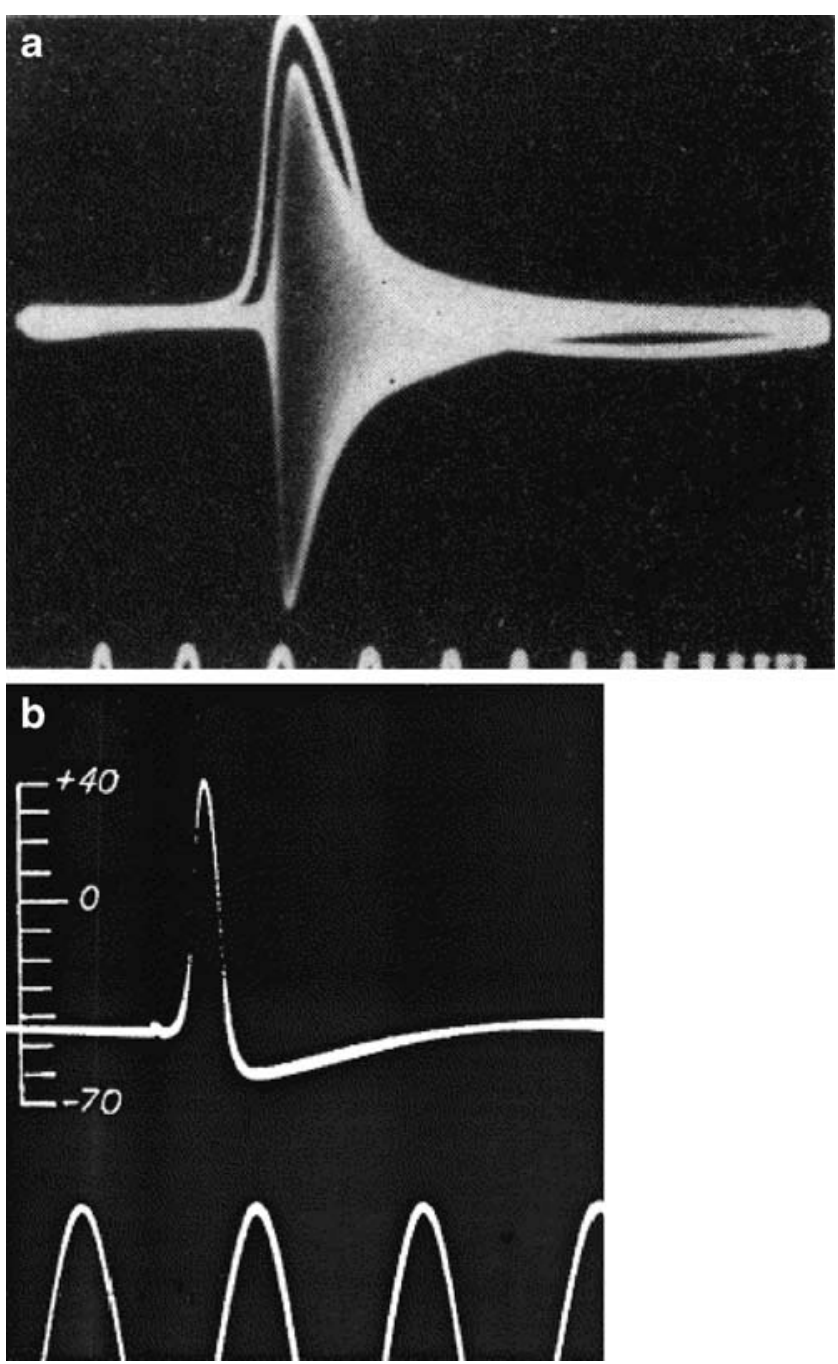

Fig. 5 First recordings from the squid axons. a The increase in conductance of the squid axon during the action potential as seen by Cole and Curtis [14]. Upper trace: action potential; white-dark band: measure of the membrane impedance obtained with the Wheatstone bridge method by applying a high frequency $(20 \mathrm{KHz})$ sinusoidal signal to two electrodes placed on the opposite site of a giant axon. The time marks at the bottom are $1 \mathrm{~ms}$ apart. b The first published intracellular recording of the action potential in the squid axon. Time mark, $500 \mathrm{~Hz}$ [27] 
measurement of the kinetics of the activity-associated electrical events with any relevant precision. This problem was brilliantly solved by Julius Bernstein, who introduced a truly remarkable piece of scientific machinery, the "differential rheotome", which allowed adequate recordings of very fast electrical processes: the sampling rate of Bernstein's rheotome was approximately several tens of microseconds (a detailed account of Bernstein' techniques was recently made by Bernd Nilius [52]). Bernstein published the description of his rheotome in the first issue of Pflügers Archiv [6], and thereby, initiated the tradition of publishing the most advanced electrophysiological techniques in this journal.

Using the rheotome, Bernstein made the first true recordings of resting and action potentials (Fig. 4). He estimated that at rest, the nerve interior is about $60 \mathrm{mV}$ more negative than the surface and showed the kinetics of the action potential (still called "negative Schwankung"). The action potential measured by Bernstein had a rise time of about $0.3 \mathrm{~ms}$ and a duration of $\sim 0.8-0.9 \mathrm{~ms}$; but most importantly, the potential deflection actually crossed the "zero potential" line causing the "sign reversal", which clearly reflected the action potential overshoot $[6,7]$. Bernstein also estimated the conduction velocity of the nerve, which was very similar $(\sim 25-30 \mathrm{~m} / \mathrm{s})$ to the data obtained by Helmholtz.

Bernstein developed several theories of electrical excitability, and in 1896, being prompted by his student Vassily Tschagovetz, he employed the electrolytic theory of Walther Nernst to biological systems and came up with the hypothesis that $\mathrm{K}^{+}$selectivity of the excitable mem-
Fig. 6 First ion currents recordings (all from [34]) a Diagram illustrating arrangement of internal and external electrodes. $\mathrm{A}_{1}, \mathrm{~A}_{2}, \mathrm{~A}_{3}$, and $\mathrm{A}_{4}$ and $\mathrm{C}$ are Perspex partitions; a, $\mathrm{b}, \mathrm{c}, \mathrm{d}$ and e are electrodes. Insulated wires are shown by dotted lines. b Diagram of internal electrode (not to scale). The pitch of each spiral was $05 \mathrm{~mm}$. The exposed portions of the wires are shown by heavy lines. c Records of membrane current under a voltage clamp. At zero time, the membrane potential was increased by $65 \mathrm{mV}$ (record A) or decreased by $65 \mathrm{mV}$ (record B); this level was then maintained constant throughout the record. Inward current is shown as an upward deflexion. Axon 41; diameter, $585 \mu \mathrm{m}$; temperature $3.8^{\circ} \mathrm{C}$

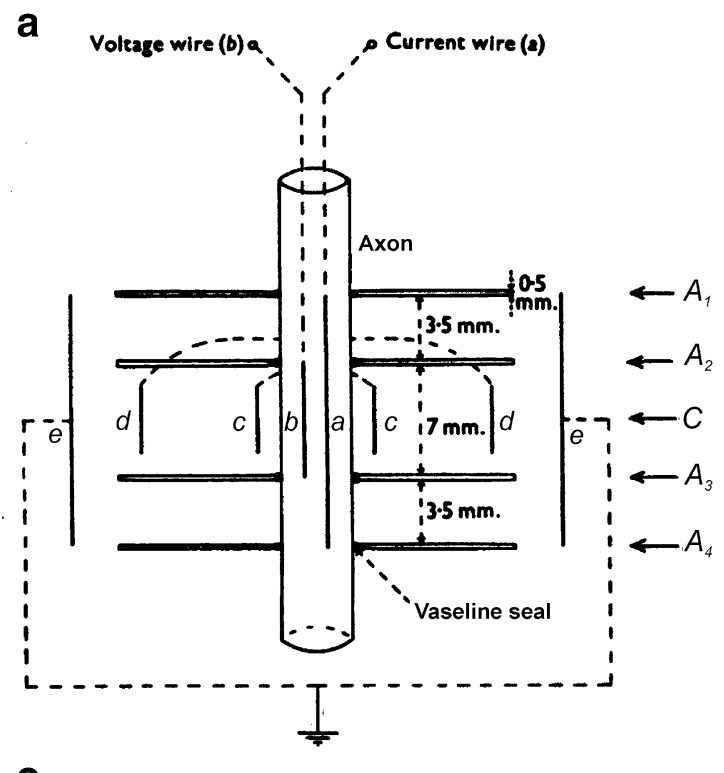

C

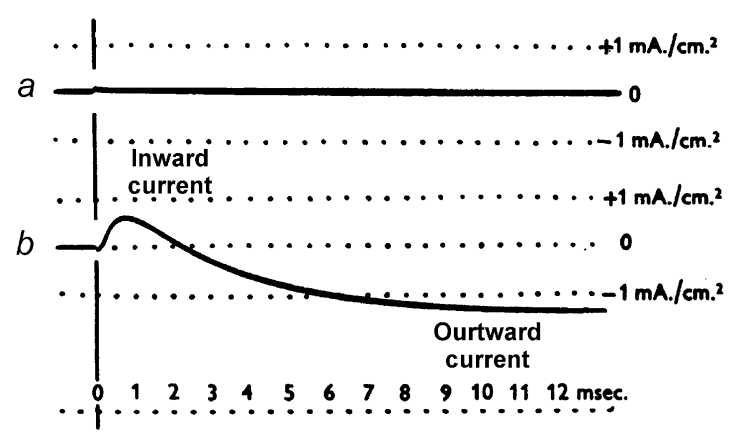

b

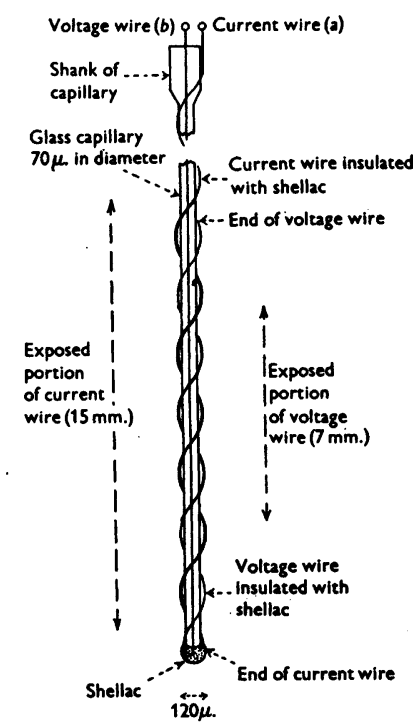

d

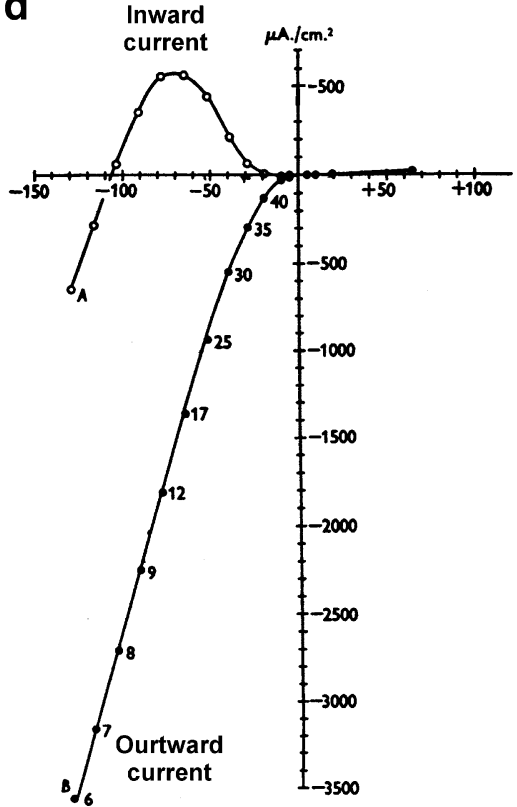


brane is responsible for the generation of the resting membrane potential $[8,9]$. This theory was further developed by Charles Ernst Overton, who demonstrated that $\mathrm{Na}^{+}$ions are required for producing the "negative Schwankung", and suggested that the excitation process results from the exchange of $\mathrm{Na}^{+}$and $\mathrm{K}^{+}$[56].

Incidentally, it was also Overton, who, in 1899, proposed a "lipoidal membrane" model of the plasmalemma, after discovering that lipid-soluble dyes enter cells substantially easier than the water-soluble ones [55]. The bilayer structure of the cellular membranes was confirmed in 1925 by Gorter and Grendel, who found that the amount of lipids, extracted from "chromocytes" (red blood cells) was sufficient to cover the surface of these cells twice (the surface area was determined from microscopic observations of blood cells), which led them to propose the lipid bilayer structure [22]. This theory was further developed by Danielli and Dawson [16], who introduced the concept of the bilayer lipid membrane which is associated with numerous proteins and is penetrated by narrow water-filled pores, which allow the passage of lipid-insoluble molecules, including ions.

All in all, by the mid-1930s, the structure of the cell membrane was known and the prototypes of ion channels suggested; yet direct physiological data were needed to accomplish the electrical theory of excitation.
Fig. 7 Extracellular electrical recordings from muscle fibers using fire-polished glass micropipettes [72, 73]. a Production of smooth tipped micropipettes. (a) Pipette tip immediately after pulling showing separation at first undulation. Tip too sharp to be used. (b) Heat flashing tip of (a) for a few seconds. Tip adequate for use. (c) Further heat flashing of tip. Tip not satisfactory for use since the leakage resistance path will be too long. b Method for local excitation and impedance recording. Modified from [72]

\section{a}
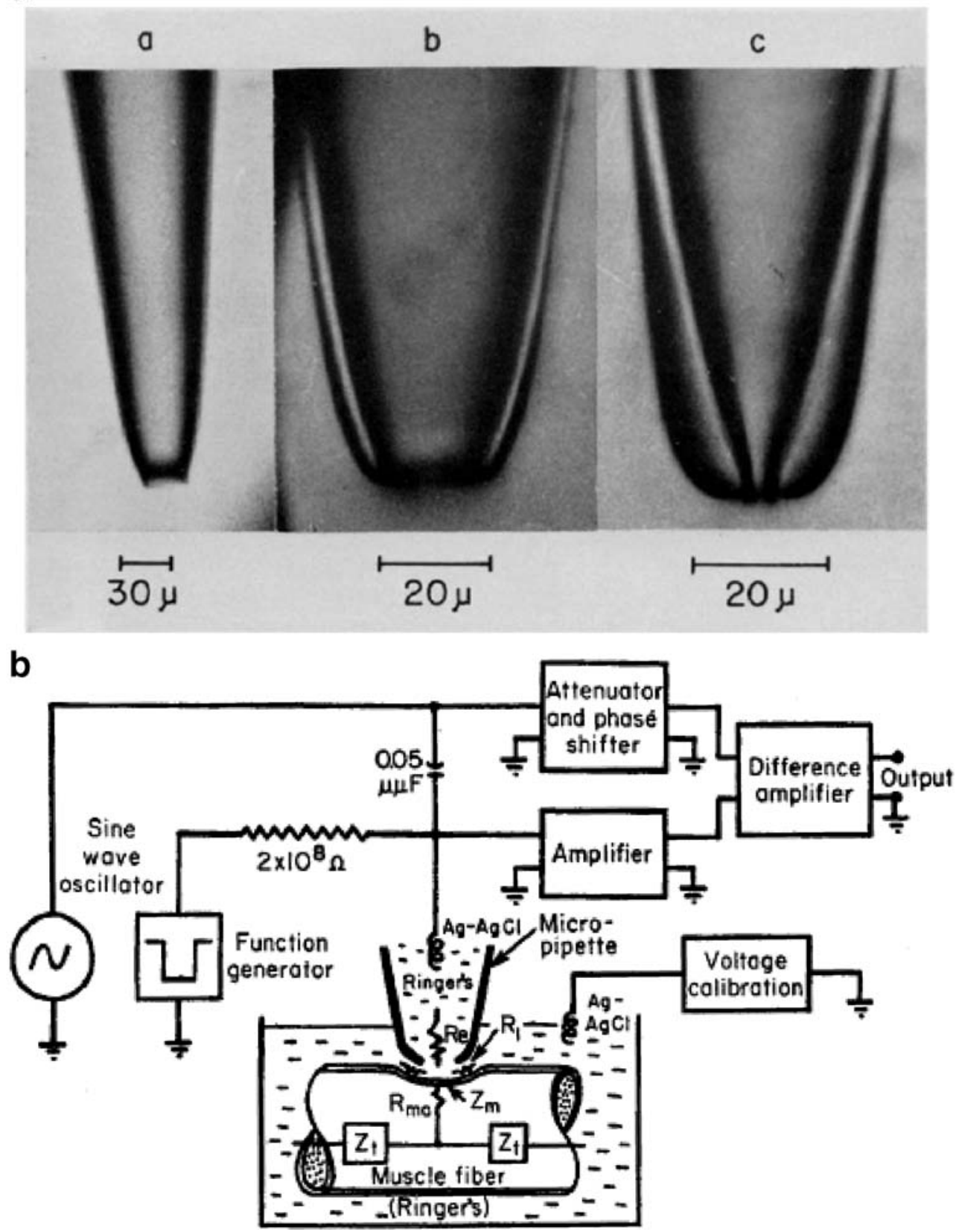


\section{The voltage clamp}

Such direct electrophysiological experiments became possible after John Z. Young introduced the squid axon into physiological practice [77]. In 1939, Kenneth Cole and Howard Curtis performed impedance measurements, using extracellular electrodes on axons isolated from the "The Atlantic squid, Loligo pealii...From early May until late June excellent animals were available, but later they were smaller, not so numerous, and did not live long in the aquarium. Slender animals were preferred because the axons were of nearly uniform diameter over their usable length." [14]. These experiments directly demonstrated the rapid fall in membrane resistance during the development of the action potential (Fig. 5a). Slightly later, both Cole and Curtis [15] and Alan Hodgkin and Andrew Huxley [27] developed intracellular electrodes, which could be inserted into the squid axon and performed the first direct recordings of action potentials (Fig. 5b). These recordings demonstrated a very clear action potential overshoot and determined the resting potential at $\sim-50 \mathrm{mV}$.

In 1949, the voltage-clamp technique was designed by Cole [13] and Marmont [43], and almost immediately, employed by Hodgkin and Huxley (Fig. 6) to produce the ionic theory of membrane excitation [28-34]. Most importantly, Hodgkin and Huxley clearly demonstrated that
Fig. 8 Extracellular voltageclamp recordings from snail neurones [49]. a Schematic diagram of the electronic system and geometry of the pipette. Current is measured with high input impedance operational amplifiers. The suboesophagael ganglion of Helix pomatia snails was mounted in a lucite chamber and the connective tissue sheath removed under a dissecting microscope. The dorsal surface was cleaned as carefully as possible and clusters of cells exposed. For voltage clamp, the neurone was impaled with an electrode made from two microelectrodes glued together with a tip separation of 20 $30 \mu \mathrm{m}$. One of them, the current electrode, was electrolytically coated with silver to within $50 \mu \mathrm{m}$ of the tip. b Simultaneous measurement of the overall intracellular clamp current (lower traces) and the current through the pipette (upper traces, inversed polarity), superimposed for 30, 40, 50 and $60 \mathrm{mV}$ depolarizing pulses. Note the late inward transients in the lowest traces, which are not present in the corresponding upper traces. Active soma current is present only for depolarizing pulses of $50 \mathrm{mV}$ and more. Modified from [49] a

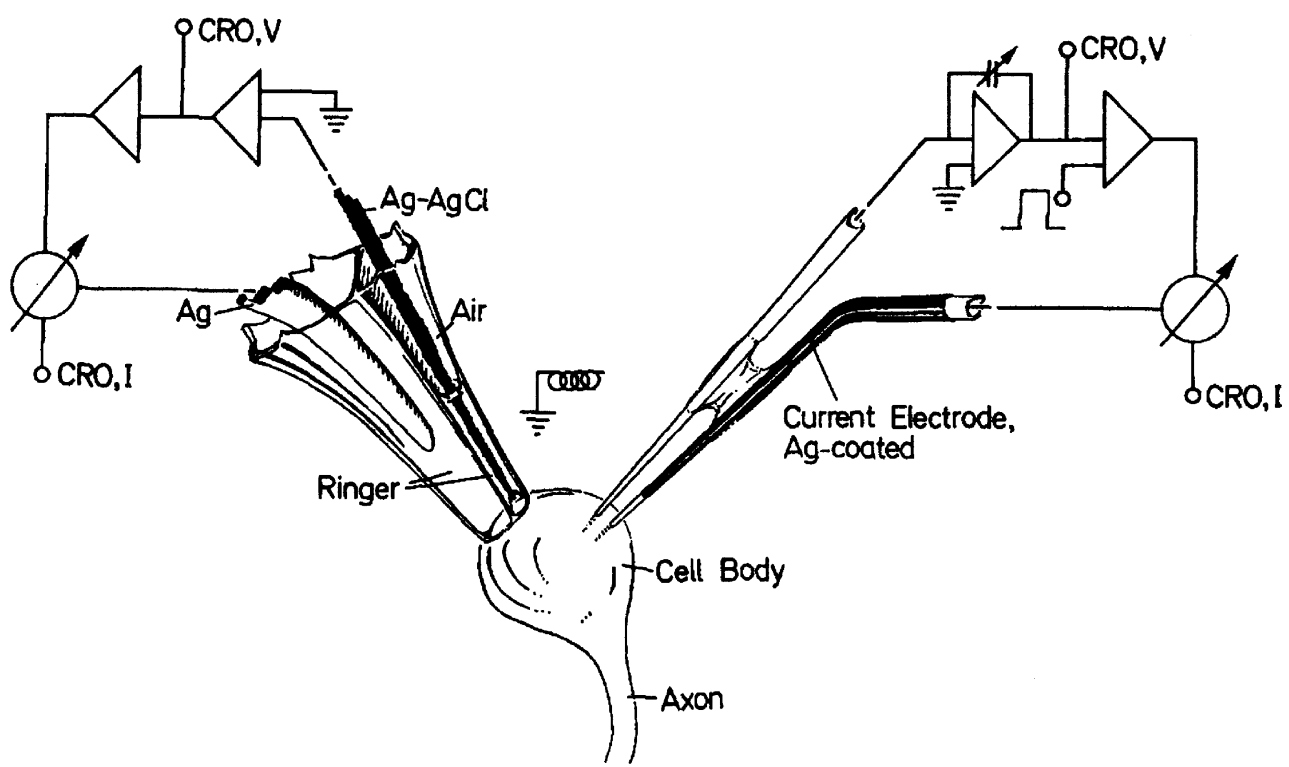

b

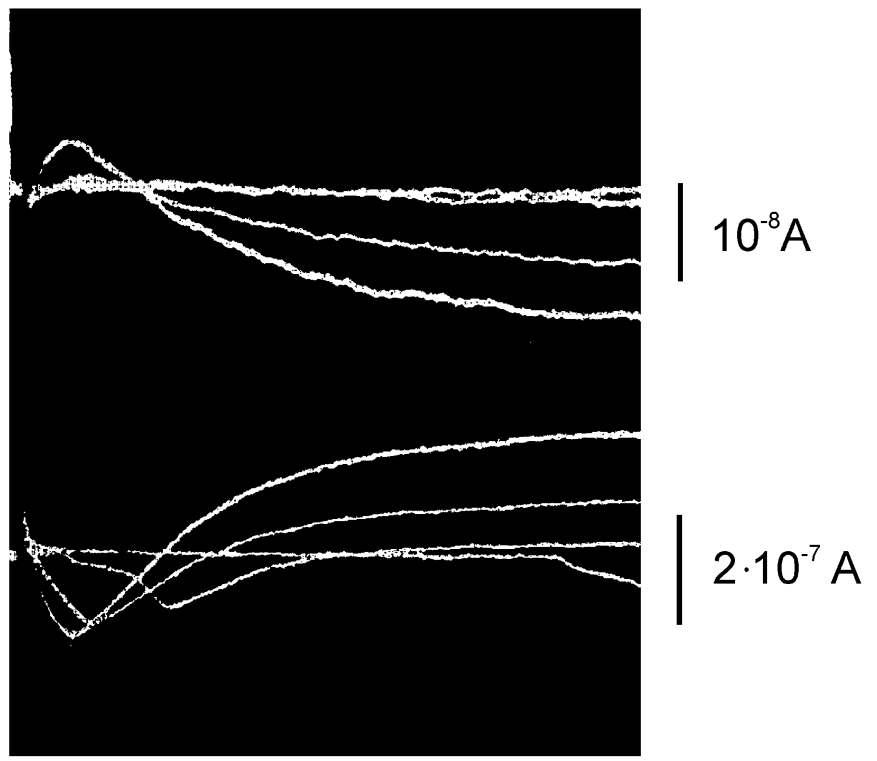


membrane excitability is determined by passive ion fluxes according to their electro-chemical gradients, which implied the existence of transmembrane aqueous pathways. Although the ion channels were not directly proposed by the theory, their existence was already suggested.

\section{The quest for ion channels}

Instrumental recordings of ion channel currents were the result of long and painful technical developments. From the very beginning, several technical barriers had to be conquered. First, further development of the ionic theory of excitation required recordings not only from axons of nonvertebrates, but also from mammalian cells, which are generally rather small and difficult to access because of tissue barriers. Second, precise separation of ion currents and dissection of the mechanisms of their regulation required control over both the extra- and intracellular environments. Third, monitoring of single ion channels currents called for low-noise recordings from exceedingly small areas of cellular membranes. All these technical challenges were solved, in parallel, by several groups of dedicated electrophysiologists; their continuous efforts finally culminated in the development of the patch-clamp technique.

a. First intracellular recordings from individual cells: microelectrodes

Microelectrodes pulled from glass pipettes and suitable for low-traumatising penetrations of individual cells were developed in 1949 by Gilbert Ling and Ralf Gerard [42]. Very soon, microelectrodes became the technique of choice for electrophysiological recordings from all types of cells; multiple electrode impalements allowed both monitoring of the membrane potential and membrane currents under voltage clamp.
Fig. 9 Intracellular perfusion techniques. a Extrusion of axoplasm [4]. A cannula filled with perfusion fluid was tied into the distal end of a giant axon of length 6-8 cm. The axon was placed on a rubber pad and axoplasm was extruded by passing a rubbercovered roller over it in a series of sweeps. The first sweep started at about $1-5 \mathrm{~cm}$ from the cut end, the second at $3 \mathrm{~cm}$ and so on. At the end of this operation, all the axoplasm had been removed except for a column, 5-10 $\mathrm{mm}$ in length near the cannula. The axon was then suspended vertically in a large beaker of sea water. The cannula was connected to a mechanically driven 'Agla' syringe and perfusion fluid was forced into the axon at about $6 \mu 1 / \mathrm{min}$. Occasionally, when the axon narrowed in the middle, the plug of axoplasm stuck, and in these instances, the experiment usually had to be abandoned. b Intracellular dialysis of snail neurone [37]. Schematic drawing of a cell fixed in the conical pore in the polyethylene film. A part of the membrane facing the compartment with artificial intracellular saline is ruptured with a pressure pulse. c Intracellular perfusion of a single cell situated between two perfusion pores [37]. 1 Unity gain input-amplifier; 2 voltage-clamp amplifier; 3 current-voltage transducer. The pathways of the perfusion are indicated by arrows. Modified from [4, 37] a
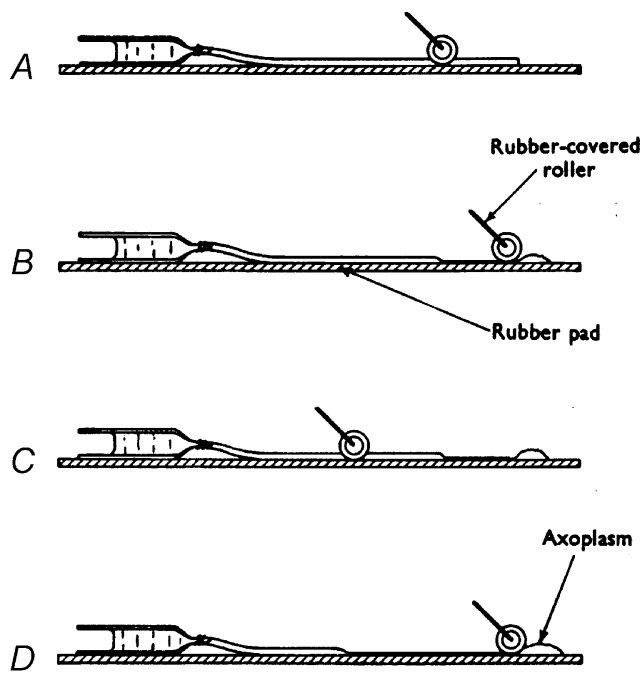

C

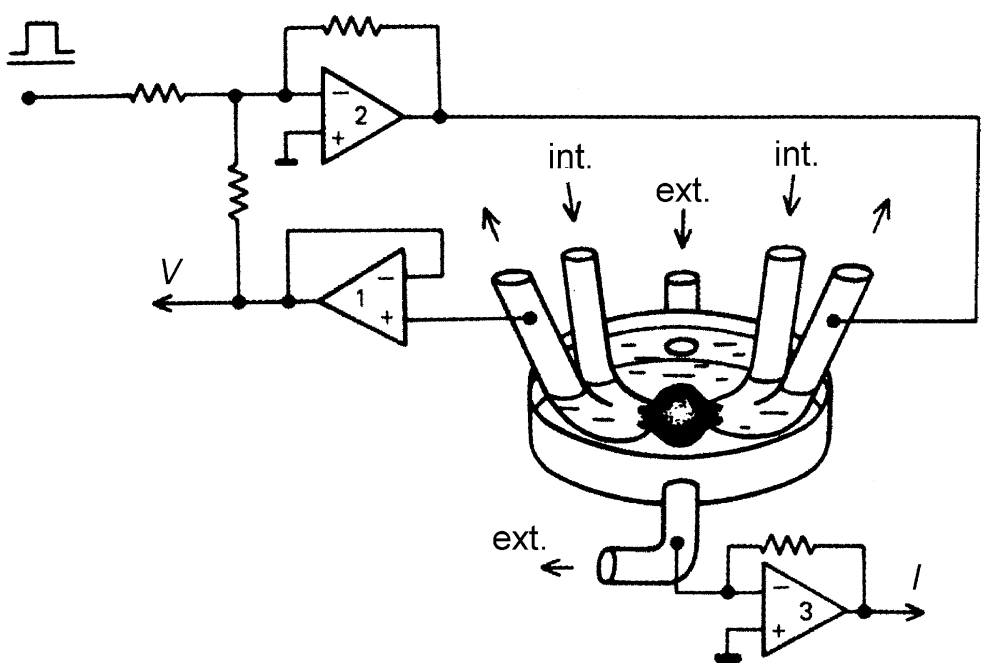




\section{b. First extracellular recordings from cell membranes}

Probably for the first time, extracellular glass electrodes were used in 1919 by Frederick Pratt and John Eisenberger [67], who manufactured a fine-pointed capillary pore electrode with an outer diameter $\sim 4-8 \mu \mathrm{m}$; these electrodes were employed for focal stimulation of single skeletal muscle fibres, which directly demonstrated that skeletal muscle excitation followed the all-or-none principle.

The first extracellular recordings from cellular membranes were performed by Alfred Strickholm [72, 73], who used a "smooth tipped, liquid-filled micropipette (several microns tip diameter)... placed against a muscle in such a way that the cell surface under it was electrically isolated except for a leakage resistance path between tip and cell [72]. Using these pipettes, he was able to measure the impedance of frog muscles and record currents, flowing through the small membrane patch under the tip of the extracellular pipette (Fig. 7). Several years later, Karl Frank and Ladislav Tauc revealed a heterogeneous distribution of $\mathrm{Na}+$ channels in molluscan neurones by voltage-clamping relatively small patches of the plasma membrane with the help of an extracellular glass micropipette [18]. In 1969, Erwin Neher and Hans Dieter Lux developed a conceptually similar technique to monitor membrane currents from the somatic membrane of sub-oesophageal ganglion neurones of Helix pomatia snails [49]. They pulled micropipettes from asymmetrical double-barrelled capillaries to obtain an opening of about $100-150 \mu \mathrm{m}$ in diameter; the tip of the pipette was subsequently fire-polished (Fig. 8). Importantly, gentle suction $(2-10 \mathrm{mmHg})$ was applied to the pipette interior, which helped the approach to the neuronal membrane in the ganglia (normally covered by glial cells) and improved the shunt resistance between the pipette wall and the cell membrane.

\section{c. Intracellular perfusion}

The first experiments with complete or partial replacement of the cytoplasm with artificial salt solution were performed on squid axons in 1961 by Peter Baker, Alan Hodgkin and Trevor Shaw [4] (Fig. 9a). About a decade later, a conceptually similar intervention was applied first to isolated mollusc neurones [35-38], and then, to different types of single mammalian cells. The initial version of intracellular perfusion was built around plastic film, which separated two chambers, filled with extra- and intracellular solutions [38] (Fig. 9b). A tiny pore (several micrometers $(\mu \mathrm{m})$ in diameter) was made in the film, and the cell soma was placed on top of the pore; a small negative pressure applied to the "intracellular" chamber helped the cell to invade the pore. After the cell firmly occluded the pore, the membrane facing the intracellular compartment was disrupted and electrical and physical access to the cell interior was gained. This initial setup was soon modified, and the planar film was replaced by either plastic or glass pipettes
[37, 40, 41], which allowed easy hunting for cells and permitted further modification of the method. These modifications included double perfusion (when the cell was fixed between two pipettes $[36,41]$, which provided for a very good spatial voltage clamp and fast and effective exchange of the intracellular milieu-Fig. 9c) and employment of plastic pipettes for extracellular recordings with the aim of measuring single-channel currents [39]. Unfortunately, all these techniques suffered from a relatively low leakage resistance between the membrane surface and the wall of the recording pipette, which prevented low-noise recordings.

d. Artificial membranes and channels

Initial evidence for discrete ion currents were obtained from experiments with artificial lipid membranes, introduced by Paul Müller and Donald Rudin in 1963 [48]. Treatment of these membranes with antibiotics (e.g., gramicidin A) or certain proteins induced an ionic conductance, which was manifested by step-like, discrete events of transmembrane currents $[5,26]$.

\section{e. The patch clamp}

In intact cells, the difficulty is to detect single-channel currents in the presence of background electrical noise. Conventional intracellular (sharp) microelectrode methods for current measurements are associated with a background noise of at least $100 \mathrm{pA}$, whereas, the current flowing when a single channel opens is only a relatively small fraction of
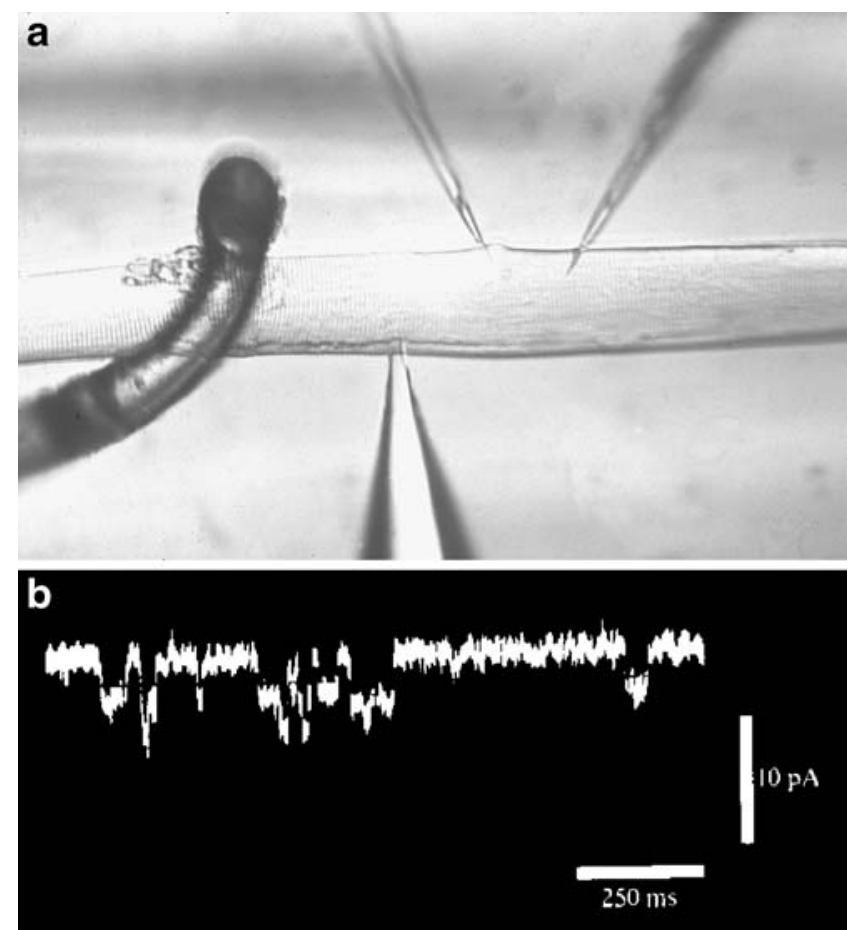

Fig. 10 First recordings of acetylcholine receptor single channel currents from denervated frog (Ram pipiens) cutaneous pectoris muscle [50]. a The photograph of the preparation. b Current recordings. The pipette contained $0.2 \mathrm{mM}$ suberyldicholine, an analogue of acetylcholine which induces very long-lived channel openings. Membrane potential- $120 \mathrm{mV}$; temperature, $8^{\circ} \mathrm{C}$. Modified from [50] 
this background noise. Neher and Sakmann [50], following up the earlier work of Neher and Lux already mentioned, pressed a smooth electrode tip on to the surface of an isolated skeletal muscle fibre, thereby, electrically isolating a patch of membrane (Fig. 10a). Intrinsic noise decreases with the area of membrane under study, and therefore, when a small area $\left(1-10 \mu \mathrm{m}^{2}\right)$ is isolated, the extraneous noise levels can be made so low that the picoampere currents flowing through single ion channels can be measured directly (Fig. 10b).

Although the first recordings of single ion channel currents (through nicotinic acetylcholine receptors) from a real biological membrane represented a huge step forward, there were limitations due to the still relatively low seal resistance (megaohms) between recording pipette and cell membrane [50]. The discovery in 1980 [69] of the high resistance (gigaohm) seal between highly cleaned and very smooth micropipette tips and smooth surface cell membranes (the socalled giga-seal), turned out to be extremely important, as it not only permitted much better electrical recordings but also allowed entirely new types of electrophysiological experiments [23]. The astonishing stability and tightness of the giga-seal interaction between micropipette and cell membrane, allowed not only electrical isolation in situ but also complete mechanical isolation of a patch of cell membrane in either the inside-out or outside-out configurations.

It was expected that patch-clamp single-channel current recording would relatively quickly reveal the key properties of the most important ion channels in electrically excitable - and indeed, also electrically non-excitable cells, and this turned out to be the case [68]. What had perhaps not been anticipated was the speed with which the patch-

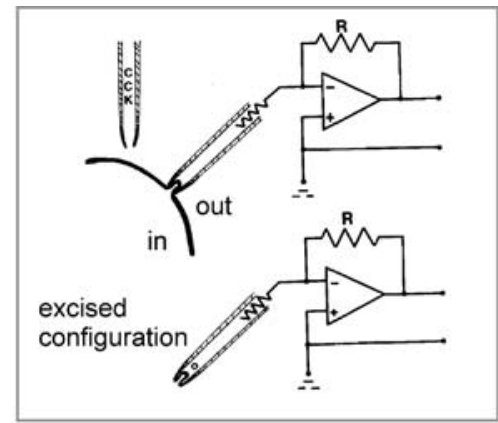

Control

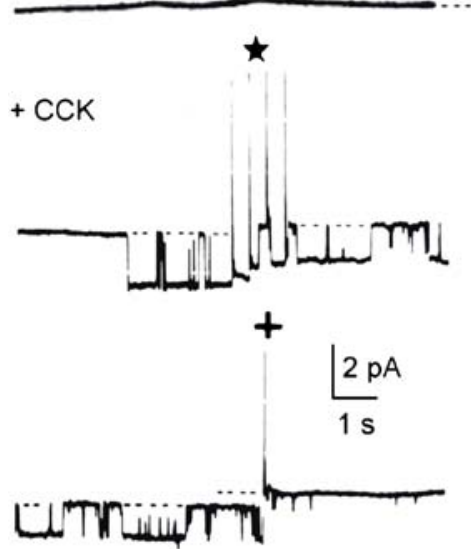

After excision

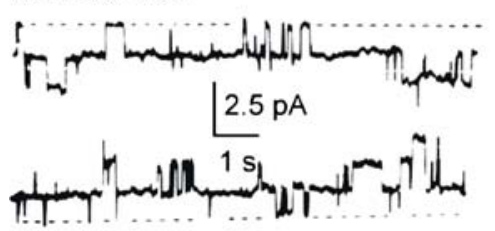

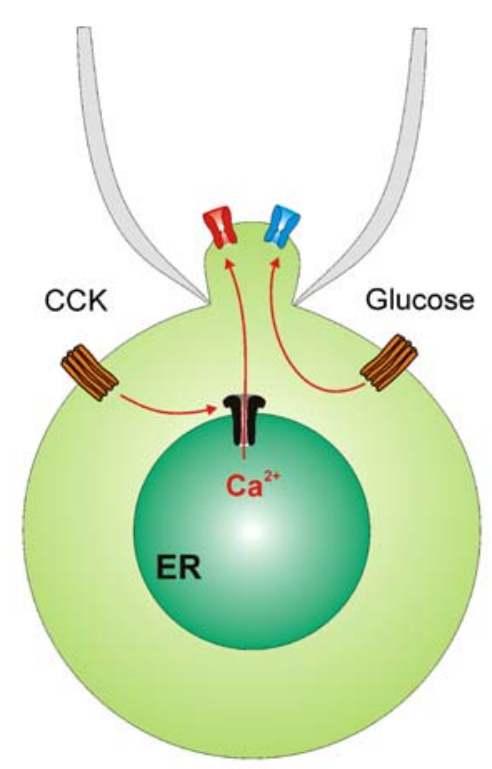
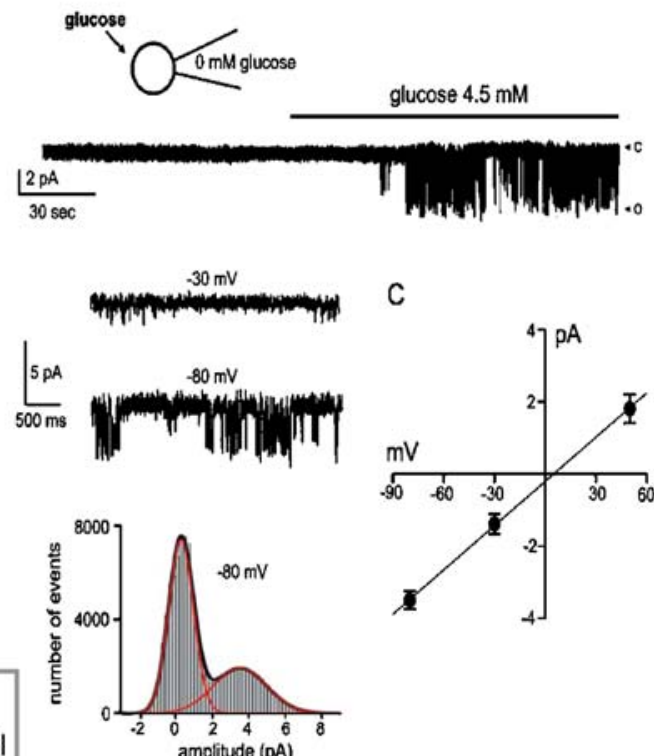

C

I. $\mathrm{Ca}^{2+}$-dependent cation channe

$\mathrm{K}^{+}$TASK channel

Plasmalemmal receptors

Intracellular $\mathrm{Ca}^{2+}$-release

channel
Fig. 11 Cell-attached patch-clamp current recording reveals messenger-mediated mechanisms by which agonists cause opening or closure of single ion channels. The figure illustrates the general principle of CCK-induced, $\mathrm{Ca}^{2+}$-mediated opening of single non-selective cation channels in intact pancreatic acinar cells (left part) and the glucose- elicited closure of $\mathrm{K}^{+}$TASK channels in intact hypothalamic orexin neurons (right part). For further details see text. The original traces in the left part are taken from Maruyama and Petersen [44] and in the right part from Burdakov et. al. [10] 
clamp technique became the workhorse of modern electrophysiology [62], how this technique would change our preferred cell models from large muscle fibres and giant axons to small round mammalian cells and how the whole-cell recording configuration-which was initially thought of as a by-product of the patch-clamp techniquebecame one of the most crucial and popular techniques for studies of signal-transduction mechanisms [59, 60].

\section{The versatility of the patch-clamp technique: role} in identification of intracellular signalling cascades

Although the invention of the patch clamp technique had been motivated principally by a desire to understand the function of the electrically excitable nerve and muscle cells, the first recordings of single-ion-channel currents from electrically non-excitable cells (pancreatic acinar cells that do not and cannot fire action potentials) were published already in 1982 [44, 45]. These studies led to the concept of agonist-induced, messenger-mediated ion channel activation (Fig. 11). By applying an agonist (the circulating peptide hormone cholecystokinin-CCK) outside the patch of membrane isolated by a patch-clamp pipette, it was possible to demonstrate directly that CCK opened single nonselective cation channels via an intracellular messenger.

Subsequent excision of the isolated membrane patch into the inside-out configuration made it possible to demonstrate that the channels opened in the intact cells by CCK stimulation were identical to channels opened in the excised patch by increasing the $\mathrm{Ca}^{2+}$ concentration in the bath solution (in contact with the physiological inside of the membrane-Fig. 11). This led to the conclusion that CCK interaction with specific plasma membrane receptors pro-

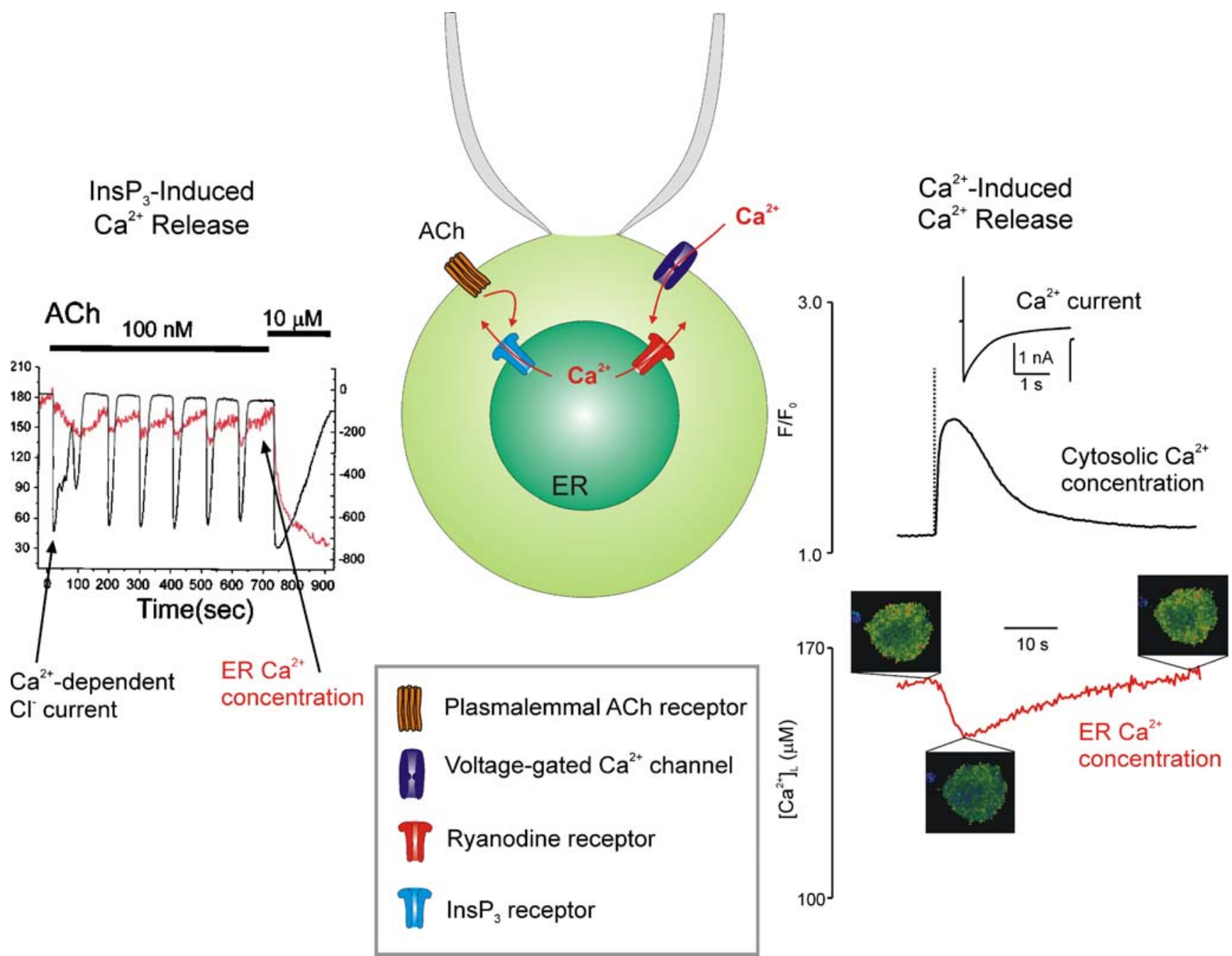

Fig. 12 Simultaneous recordings of patch-clamp whole-cell currents and $\left[\mathrm{Ca}^{2+}\right]$ in the cytosol and the endoplasmic reticulum. The figure illustrates the principal mechanisms by which cytosolic $\mathrm{Ca}^{2+}$ signals are generated in pancreatic acinar cells by $\mathrm{IP}_{3}$-mediated $\mathrm{Ca}^{2+}$ release from the ER in response to acetylcholine (ACh) stimulation (left part) and in sensory neurons by $\mathrm{Ca}^{2+}$-induced $\mathrm{Ca}^{2+}$ release triggered by $\mathrm{Ca}^{2+}$ inflow through voltage-gated $\mathrm{Ca}^{2+}$ channels in the plasma membrane in response to membrane depolarization (right part). For further details see text. The original traces in the left part are from Park et al. [58], and in the right part, from Solovyova et al. [70] 
Fig. 13 Photo of the participants in the meeting held at the Klaus Tschira Foundation, Heidelberg, Germany, March/April 2006. Four of the authors of the celebrated giga-seal methods paper [23] were present: (1) Bert Sakmann (between Eva Sykova, left and Ole Petersen, right); (2) Erwin Neher (between Oleg Krishtal, left and Alex Verkhratsky, right); (3) Alain Marty (next to Bernd Nilius, right) and (4) Owen Hamill (between Emilio Carbone, left and Michael Brecht, right). Unfortunately, Fred Sigworth was unable to attend

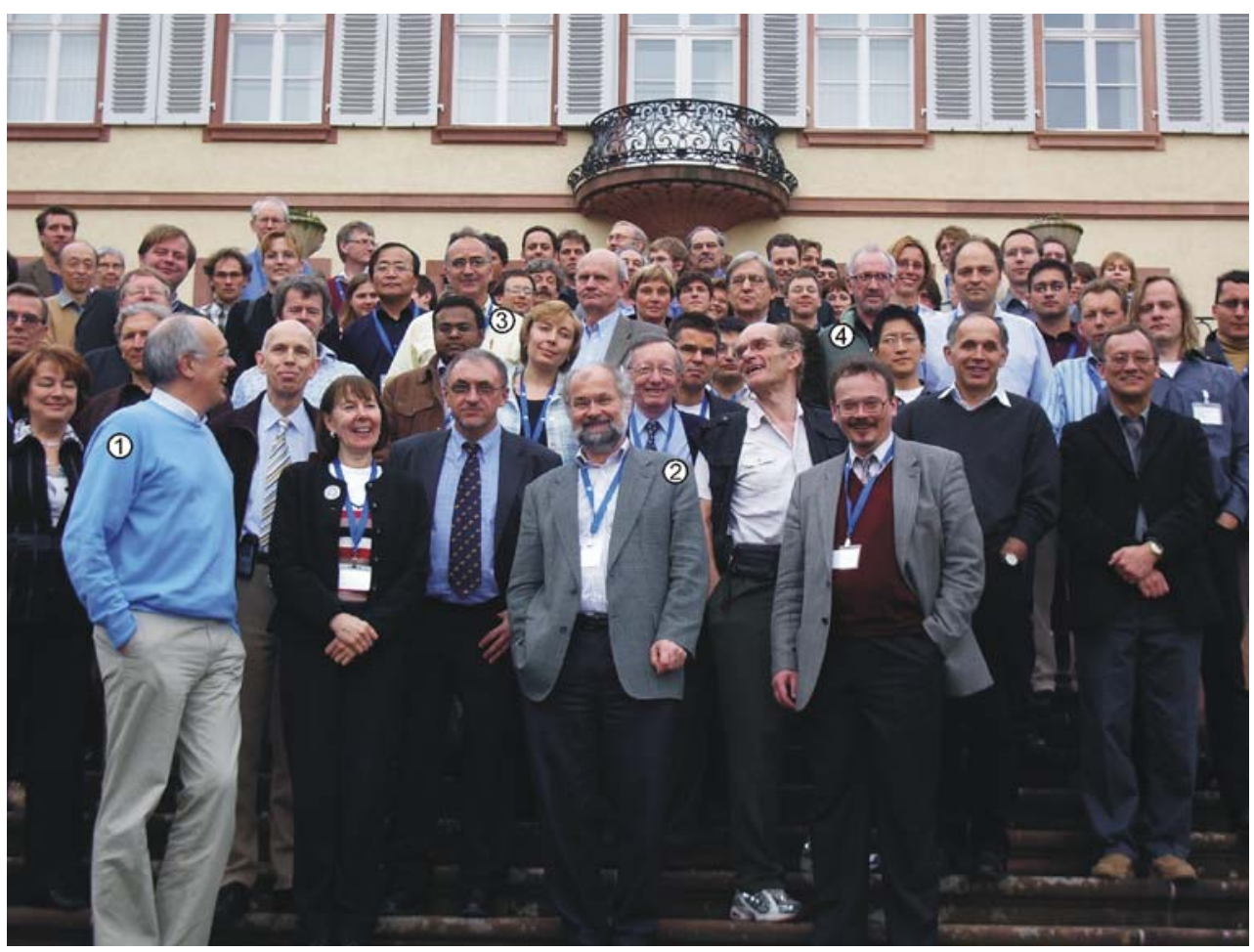

duces a messenger cascade (now thought to generate primarily the $\mathrm{Ca}^{2+}$-releasing messenger nicotinic acid adenine dinucleotide phosphate, but relying on $\mathrm{Ca}^{2+}$ release from the endoplasmic reticulum via both inositol trisphosphate $\left(\mathrm{IP}_{3}\right)$ receptors and ryanodine receptors [60])resulting in a rise in the cytosolic $\left[\mathrm{Ca}^{2+}\right]$, which then activates $\mathrm{Ca}^{2+}$-dependent non-selective cation channels and-importantly, as shown later- $\mathrm{Ca}^{2+}$-dependent $\mathrm{Cl}^{-}$channels [58].

More recently, a similar approach has been used to identify the mechanism by which glucose inhibits the electrical activity of orexin neurons in the hypothalamus [10] (Fig. 11). In this study, it was demonstrated that application of glucose outside a patch of membrane isolated by a patch pipette on the surface of an intact orexin/ hypocretin neuron could open tandem pore $\mathrm{K}^{+}$channels $\left(\mathrm{K}_{2 \mathrm{P}}\right)$ (Fig. 11). This is a physiologically important process, sensitive to physiological variations in the plasma glucose concentration. Interestingly, and in sharp contrast to what happens in the pancreatic insulin-secreting beta-cells $[3,61]$ where glucose-induced closure of ATP/ADP-sensitive $\mathrm{K}^{+}$ channels only occurs in response to metabolism of glucose inside the cells, glucose acts specifically on the outside of the surface cell membrane of the orexin neurons (Fig. 11). The intracellular messenger is still unknown, but would appear not to be ATP, $\mathrm{Ca}^{2+}$ or glucose itself [10].

Increasingly, the patch-clamp technique is used in conjunction with measurements of $\left[\mathrm{Ca}^{2+}\right]$ in the cytosol [54] and other intracellular compartments. This approach has proven very useful in identifying mechanisms of cytosolic $\mathrm{Ca}^{2+}$ signal generation in electrically excitable and non-excitable cells. Fig. 12 shows two examples of such experiments. In pancreatic acinar cells, both the neurotransmitter acetylcholine (ACh), activating muscarinic receptors and CCK can produce cytosolic $\mathrm{Ca}^{2+}$ signals that are important for stimulating exocytotic secretion of digestive enzymes and fluid [63]. Fig. 12 illustrates the mechanism by which a relatively low ACh concentration (100 nM) generates repetitive cytosolic $\mathrm{Ca}^{2+}$ spikes, recorded as spikes of $\mathrm{Ca}^{2+}$-dependent $\mathrm{Cl}^{-}$currents. The patch clamp whole-cell current recording is combined with optical measurement, using a low-affinity fluorescent $\mathrm{Ca}^{2+}$ sensor, of $\left[\mathrm{Ca}^{2+}\right]$ in the endoplasmic reticulum (ER) [57]. It can be seen that each increase in inward $\mathrm{Cl}^{-}$current (outflux of $\mathrm{Cl}^{-}$) is associated with a decrease in $\left[\mathrm{Ca}^{2+}\right]_{\mathrm{ER}}$ and that $\left[\mathrm{Ca}^{2+}\right]_{\mathrm{ER}}$ increases in the interval between spikes $\left(\mathrm{Ca}^{2+}\right.$ reuptake into the ER driven by the $\mathrm{ER} \mathrm{Ca}^{2+}$ pump). From a physiological perspective, it is important to note that the decrease in $\left[\mathrm{Ca}^{2+}\right]_{\mathrm{ER}}$ generating each short-lasting $\mathrm{Ca}^{2+}$ spike is quite small, as seen when comparison is made with the marked decrease in $\left[\mathrm{Ca}^{2+}\right]_{\mathrm{ER}}$ occurring in response to supra-maximal ACh stimulation at the end of the experiment (Fig. 12).

This type of approach has also been very helpful in demonstrating, for the first time, directly $\mathrm{Ca}^{2+}$-induced $\mathrm{Ca}^{2+}$ release in neurons [75]. Figure 12 illustrates an experiment in which measurements of $\left[\mathrm{Ca}^{2+}\right]$ in both cytosol and ER were combined with patch clamp whole-cell $\mathrm{Ca}^{2+}$ current recording. Inward $\mathrm{Ca}^{2+}$ current was triggered by membrane depolarization, causing a rise in $\left[\mathrm{Ca}^{2+}\right]_{\mathrm{i}}$ triggering a decrease in $\left[\mathrm{Ca}^{2+}\right]_{\mathrm{ER}}[70]$. 


\section{The meeting}

The very highly cited methods paper describing the gigaseal patch clamp technique [23] was published 25 years ago and to celebrate 25 years of giga-seal patch clamping and the very many important results obtained with this technology. A symposium took place in Heidelberg, Germany in the period 30 March-1 April 2006 (Fig. 13). This special issue consists of the written versions of the majority of the invited lectures held at this meeting.

Acknowledgements We gratefully acknowledge the financial assistance from the Klaus Tschira Foundation, Springer Verlag, HEKA, FLYION and NANION, as well as the administrative help from Academia Europaea, which made this symposium possible.

\section{References}

1. Aldini G (1803) An account of the late improvements in galvanism, with a series of curious and interesting experiments performed before the commissioners of the French National Institute, and repeated lately in the anatomical theaters of London, by John Aldini

2. Aldini G (1804) Essai théorique et expérimental sur le galvanisme vol. 2. Fournier et Fils, Paris

3. Ashcroft FM, Harrison DE, Ashcroft SJ (1984) Glucose induces closure of single potassium channels in isolated rat pancreatic beta-cells. Nature 312:446-448

4. Baker PF, Hodgkin AL, Shaw TI (1962) Replacement of the axoplasm of giant nerve fibres with artificial solutions. J Physiol 164:330-354

5. Bean RC, Shepherd WC, Chan H, Eichner J (1969) Discrete conductance fluctuations in lipid bilayer protein membranes. J Physiol 53:741-757

6. Bernstein J (1868) Ueber den zeitlichen Verlauf der negativen Schwankung des Nervenstroms. Pflügers Arch 1:173-207

7. Bernstein J (1871) Untersuchungen uber den Erregungsvorgang im Nerven- und Muskelsystem. Winter's Unisersitatsbuchhandlung, Heidelberg

8. Bernstein J (1902) Untersuchingenzurb Thermodynamik der bioelectrischen Strome. Pflügers Arch 92:512-562

9. Bernstein J (1912) Elektrobiologie-Die Lehre von den electrischen Vorgangen im Organismus auf moderner Grundlage dargestellt. Vieweg und Sohn, Braunschweig

10. Burdakov D, Jensen LT, Alexopoulos H, Williams RH, Fearon IM, O'Kelly I, Gerasimenko O, Fugger L, Verkhratsky A (2006) Tandem-pore $\mathrm{K}^{+}$channels mediate inhibition of orexin neurons by glucose. Neuron 50:711-722

11. Cobb M (2002) Malpighi, Swammerdam and the colourful silkworm: replication and visual representation in early modern science. Ann Sci 59:111-117

12. Cobb M (2002) Timeline: exorcizing the animal spirits: Jan Swammerdam on nerve function. Nat Rev Neurosci 3:395-400

13. Cole KS (1949) Dynamic electrical characteristics of the squid axon membrane. Arch Sci Physiol 3:253-258

14. Cole KS, Curtis HJ (1939) Electric impedance of the squid giant axon during activity. J Gen Physiol 22:649-670

15. Curtis HJ, Cole KS (1940) Membrane action potentials from the squid giant axon. J Cell Comp Physiol 15:147-157

16. Danielli JF, Davson H (1935) A contribution to the theory of permeability of thin films. J Cell Comp Physiol 5:495-508
17. du Bois-Reymond E (1884) Untersuchungen über thierische elektricität, 1848-1884 (2 bande). Reimer, Berlin

18. Frank K, Tauc L (1963) Voltage clamp studies on molluscan neuron membrane properties. In: Hoffman J (ed) The cellular function of membrane transport. Prentice Hall, Englewood Cliffs, New Jersey

19. Galvani L (1791) De viribus electricitatis in motu musculari commentarius. Bon Sci Art Inst Acad Comm 7:363-418

20. Galvani L (1794) Dell'uso e dell'attività dell'arco conduttore. S. Tommaso d'Aquino

21. Galvani L (1841) Opere edite ed inedite del Professore Luigi Galvani raccolte e pubblicate dall'Accademia delle Science dell'Istituto di Bologna. Dall'Olmo, Bologna

22. Gorter E, Grendel F (1925) On bimolecular layers of lipids on the chromocytes of the blood. J Exp Med 41:439-443

23. Hamill OP, Marty A, Neher E, Sakmann B, Sigworth FJ (1981) Improved patch-clamp techniques for high-resolution current recording from cells and cell-free membrane patches. Pflugers Arch 391:85-100

24. Helmholtz H (1850) Note sur la vitesse de propagation de l'agent nerveux dans les nerfs rachidiens. C R Acad Sci (Paris) 30:204 206

25. Helmholtz H (1852) Messungen über fortpflanzungsgeschwindigkeit der reizung in den nerven-zweite reihe. Arch Anat Physiol Wiss Med 199-216

26. Hladky SB, Haydon DA (1970) Discreteness of conductance change in bimolecular lipid membranes in the presence of certain antibiotics. Nature 225:451-453

27. Hodgkin AL, Huxley AF (1939) Action potentials recorded from inside a nerve fibre. Nature 144:710-711

28. Hodgkin AL, Huxley AF (1952) The components of membrane conductance in the giant axon of Loligo. J Physiol 116:473-496

29. Hodgkin AL, Huxley AF (1952) Currents carried by sodium and potassium ions through the membrane of the giant axon of Loligo. J Physiol 116:449-472

30. Hodgkin AL, Huxley AF (1952) The dual effect of membrane potential on sodium conductance in the giant axon of Loligo. J Physiol 116:497-506

31. Hodgkin AL, Huxley AF (1952) Movement of sodium and potassium ions during nervous activity. Cold Spring Harb Symp Quant Biol 17:43-52

32. Hodgkin AL, Huxley AF (1952) Propagation of electrical signals along giant nerve fibers. Proc R Soc Lond B Biol Sci 140:177183

33. Hodgkin AL, Huxley AF (1952) A quantitative description of membrane current and its application to conduction and excitation in nerve. J Physiol 117:500-544

34. Hodgkin AL, Huxley AF, Katz B (1952) Measurement of current-voltage relations in the membrane of the giant axon of Loligo. J Physiol 116:424-448

35. Kostyuk PG, Krishtal OA, Pidoplichko VI (1975) Effect of internal fluoride and phosphate on membrane currents during intracellular dialysis of nerve cells. Nature 257:691-693

36. Kostyuk PG, Krishtal OA, Pidoplichko VI (1977) Asymmetrical displacement currents in nerve cell membrane and effect of internal fluoride. Nature 267:70-72

37. Kostyuk PG, Krishtal OA, Pidoplichko VI (1981) Intracellular perfusion. J Neurosci Methods 4:201-210

38. Kryshtal OA, Pidoplichko VI (1975) Intracellular perfusion of the giant neurons of snails (in Russian). Neirofiziologiia 7:327-329

39. Kryshtal OA, Pidoplichko VI (1977) Analysis of current fluctuations shunted from small portions of the membrane of a nerve cell soma (in Russian). Neirofiziologiia 9:644-646

40. Lee KS, Akaike N, Brown AM (1978) Properties of internally perfused, voltage-clamped, isolated nerve cell bodies. J Gen Physiol 71:489-507 
41. Lee KS, Akaike N, Brown AM (1980) The suction pipette method for internal perfusion and voltage clamp of small excitable cells. J Neurosci Methods 2:51-78

42. Ling GN, Gerard RW (1949) The normal membrane potential of frog sartorius fibers. J Cell Comp Physiol 34:383-396

43. Marmont G (1949) Studies on the axon membrane. I. A new method. J Cell Comp Physiol 34:351-382

44. Maruyama Y, Petersen OH (1982) Cholecystokinin activation of single-channel currents is mediated by internal messenger in pancreatic acinar cells. Nature 300:61-63

45. Maruyama Y, Petersen OH (1982) Single-channel currents in isolated patches of plasma membrane from basal surface of pancreatic acini. Nature 299:159-161

46. Matteucci C (1842) Deuxième mémoire sur le courant électrique propre de la grénouille et sur celui des animaux à sang chaud. Ann Chim Phys 6:301-339

47. Matteucci C (1938) Sur le courant électrique ou propre de la grénouille. Bibl Univ Genève 15:157-168

48. Mueller P, Rudin DO (1963) Induced excitability in reconstituted cell membrane structure. J Theor Biol 4:268-280

49. Neher E, Lux HD (1969) Voltage clamp on Helix pomatia neuronal membrane; current measurement over a limited area of the soma surface. Pflugers Arch 311:272-277

50. Neher E, Sakmann B (1976) Single-channel currents recorded from membrane of denervated frog muscle fibres. Nature 260:799-802

51. Newton I (1713) Principia Mathematica (2nd edition). English translation by Andrew Motte, Sir Isaac Newton's Mathematical Principles of Natural Philosophy and his System of the World (1729, reprinted 1934 by the University of California Press)

52. Nilius B (2003) Pflugers Archiv and the advent of modern electrophysiology. From the first action potential to patch clamp. Pflugers Arch 447:267-271

53. Nobili L (1828) Comparaison entre les deux galvanometres les plus sensibles, la grenouille et le moltiplicateur a deux aiguilles, suivie de quelques resultats noveaux. Ann Chim Phys 38:225-245

54. Osipchuk YV, Wakui M, Yule DI, Gallacher DV, Petersen OH (1990) Cytoplasmic $\mathrm{Ca}^{2+}$ oscillations evoked by receptor stimulation, G-protein activation, internal application of inositol trisphosphate or $\mathrm{Ca}^{2+}:$ simultaneous microfluorimetry and $\mathrm{Ca}^{2+}$ dependent $\mathrm{Cl}^{-}$current recording in single pancreatic acinar cells. EMBO J 9:697-704

55. Overton CE (1899) Über die Allgemeinen Osmotischen Eigenschaften der Zelle, ihre vermutlichen Ursachen und ihre Bedeutung für die Physiologie. Vierteljahrsschrift der Naturforschenden Gesellschaft in Zürich 44:88-135

56. Overton CE (1902) Betrage zur allgemaine Muskel-und Nervenphysiologie. II Uber die Unentbehrlichkeit von Natrium- (oder Litium-) Ionen fur den Contractionsact des Muskels. Pflugers Arch 92:346-380

57. Park MK, Petersen OH, Tepikin AV (2000) The endoplasmic reticulum as one continuous $\mathrm{Ca}^{2+}$ pool: visualization of rapid $\mathrm{Ca}^{2+}$ movements and equilibration. EMBO J 19:5729-5739
58. Park MK, Lomax RB, Tepikin AV, Petersen OH (2001) Local uncaging of caged $\mathrm{Ca}^{2+}$ reveals distribution of $\mathrm{Ca}^{2+}$-activated $\mathrm{Cl}^{-}$ channels in pancreatic acinar cells. Proc Natl Acad Sci U S A 98:10948-10953

59. Petersen OH (1992) Stimulus-secretion coupling: cytoplasmic calcium signals and the control of ion channels in exocrine acinar cells. J Physiol 448:1-51

60. Petersen $\mathrm{OH}$ (2005) $\mathrm{Ca}^{2+}$ signalling and $\mathrm{Ca}^{2+}$-activated ion channels in exocrine acinar cells. Cell Calcium 38:171-200

61. Petersen OH, Findlay I (1987) Electrophysiology of the pancreas. Physiol Rev 67:1054-1116

62. Petersen OH, Michalak M, Verkhratsky A (2005) Calcium signalling: past, present and future. Cell Calcium 38:161-169

63. Petersen $\mathrm{OH}$, Sutton $\mathrm{R}(2006) \mathrm{Ca}^{2+}$ signalling and pancreatitis: effects of alcohol, bile and coffee. Trends Pharmacol Sci 27:113120

64. Piccolino M (1997) Luigi Galvani and animal electricity: two centuries after the foundation of electrophysiology. Trends Neurosci 20:443-448

65. Piccolino M (1998) Animal electricity and the birth of electrophysiology: the legacy of Luigi Galvani. Brain Res Bull 46:381-407

66. Piccolino M (2003) A "Lost time" between science and literature: the "Temps Perdu" from Hermann von Helmholtz to Marcel Proust. Audiological Medicine 1:1-10

67. Pratt FH, Eisenberger JP (1919) The quantal phenomena in muscle: methods, with further evidence of the all-or-none principle for the skeletal fiber. Amer J Physiol 49:1-54

68. Sakmann B, Neher E (1984) Patch clamp techniques for studying ionic channels in excitable membranes. Annu Rev Physiol 46:455-472

69. Sigworth FJ, Neher E (1980) Single $\mathrm{Na}^{+}$channel currents observed in cultured rat muscle cells. Nature 287:447-449

70. Solovyova N, Veselovsky N, Toescu EC, Verkhratsky A (2002) $\mathrm{Ca}^{2+}$ dynamics in the lumen of the endoplasmic reticulum in sensory neurons: direct visualization of $\mathrm{Ca}^{2+}$-induced $\mathrm{Ca}^{2+}$ release triggered by physiological $\mathrm{Ca}^{2+}$ entry. EMBO J 21:622-630

71. Stillings D (1975) Did Jan Swammerdam beat Galvani by 134 years? Med Instrum 9:226

72. Strickholm A (1961) Impedance of a small electrically isolated area of the muscle cell surface. J Gen Physiol 44:1073-1088

73. Strickholm A (1962) Excitation currents and impedance of a small electrically isolated area of the muscle cell surface. J Cell Comp Physiol 60:149-167

74. Swammerdam J (1758) The book of nature (Biblia naturae). Seyfert, London

75. Verkhratsky A (2005) Physiology and pathophysiology of the calcium store in the endoplasmic reticulum of neurons. Physiol Rev 85:201-279

76. Volta A (1918) Le opere di Alessandro Volta (edizione nazionale, 2 vols). Hoepli, Milano

77. Young JZ (1936) Structure of nerve fibres and synapses in some invertebrates. Cold Spring Harb Symp Quant Biol 4:1-6 